\title{
Reformasi Pendidikan Menghadapi Tantangan Abad 21
}

\author{
Wita Anggraini ${ }^{1}$, Hudaidah $^{2}$ \\ ${ }^{1,2}$ Program Studi Pendidikan Matematika, Fakultas Keguruan dan Ilmu Pendidikan, Universitas Sriwijaya, \\ Jl. Raya Palembang-Prabumulih Km. 32, Indralaya, Indonesia \\ witaanggraini10@gmail.com
}

\begin{abstract}
This article will focus on what kind of education system and human resources are needed in the next century. Based on this knowledge, several alternative solutions are provided to solve problems in our education system to "produce quality human resources for the future". The research method used in this research is literature study method. The literature study method is a method used by the author by searching, collecting, digging, or examining various references or documents related to the topic being proposed, for this study one related article was used to support research supported by various other research sources. Then use content analysis techniques with historical and philosophical methods for analysis. From the research conducted, it is known that the changes that must be made in the field of education in the 21 st century, namely the Indonesian curriculum, which forces students to read too much material, should be reproduced in practice. The assessment system in schools should emphasize process rather than results. In addition, learning facilities also need to be improved evenly in all regions of Indonesia. Quality human resources are needed in this global era. To produce quality human resources, of course, qualified educators are also needed. So that Indonesia will be more advanced with the next generation of nations who are able to compete with foreign nations.
\end{abstract}

Keywords: reform, education, and challenges of the $21^{\text {st }}$ century.

\begin{abstract}
ABSTRAK
Artikel ini fokus pada sistem pendidikan dan sumber daya manusia seperti apa yang dibutuhkan di abad mendatang. Berdasarkan pengetahuan tersebut, beberapa alternatif solusi disediakan untuk menyelesaikan permasalahan dalam sistem pendidikan kita untuk "menghasilkan sumber daya manusia yang berkualitas untuk masa depan". Metode penelitian yang digunakan dalam penelitian ini adalah metode studi literatur. Metode studi literatur adalah metode yang digunakan penulis dengan mencari, mengumpulkan, menggali, atau memeriksa berbagai referensi atau dokumen yang berkaitan dengan topik yang diajukan, untuk penelitian ini digunakan satu artikel terkait untuk menunjang penelitian dengan didukung dari berbagai sumber penelitian lainnya. Kemudian menggunakan teknik analisis isi dengan metode historis dan filosofis untuk analisis. Dari penelitian yang dilakukan, diketahui bahwa perubahan yang harus dilakukan dalam bidang pendidikan di abad 21 yaitu pada kurikulum Indonesia yang memaksa siswa terlalu banyak membaca materi, seharusnya praktiknya yang diperbanyak. Sistem penilaian dalam sekolah harusnya lebih ditekankan pada proses daripada hasil. Selain itu, fasilitas belajar juga perlu ditingkatkan lagi pemerataannya di seluruh wilayah Indonesia. Sumber daya manusia yang berkualitas sangat diperlukan di era global seperti sekarang ini. Untuk menghasilkan sumber daya manusia yang berkualitas tentu diperlukan tenaga pendidik yang berkualitas pula. Sehingga Indonesia akan semakin maju dengan adanya generasi penerus bangsa yang mampu bersaing dengan bangsa luar.
\end{abstract}

Kata kunci: reformasi, pendidikan, dan tantangan abad 21

Copyright (C) 2021 Wita Anggraini, Hudaidah

$\triangle$ Corresponding author: Wita Anggraini

Email Address: witaanggraini10@gmail.com (Jl. Raya Palembang-Prabumulih Km. 32, Indralaya, Indonesia)

Received 22 March 2020, Accepted 24 April 2020, Published 30 April 2021

\section{PENDAHULUAN}

Indonesia sudah cukup lama merdeka, dimana umur Indonesia sekarang cukup tua yaitu tujuh puluh lima tahun. Jika diibaratkan seperti manusia, maka negara ini sudah rentan terkena penyakit yang bisa menyebabkan kematian. Untuk menyembuhkannya maka diperlukan obat yang banyak. Salah satunya meningkatkan kualitas pendidikan di Indonesia. Sebab Indonesia merupakan negara kaya dimana rugi apabila kekayaan tersebut tidak bisa dimanfaatkan bangsa Indonesia karena tidak 
didukung oleh pengetahuan yang memadai. Terutama kekayaan alamnya, inilah tanah kiriman surga, dan juga panorama bentangan kekayaan alam Indonesia yang terhampar luas di seluruh penjuru Indonesia. Dari sabang sampai merauke yang terdiri dari 34 provinsi dan 13.466 pulau (Sithu, 2015). Sumber daya alam yang melimpah dan sumber daya hayati yang meliputi darat maupun perairan tersedia.

Lautan tiada bertepi itulah pula pribahasa yang pas untuk menggambarkan keluasan laut Indonesia yang menyimpan kekayaan alam. Begitu kaya nya limpahan lumbung perairan yang membentang di indonesia. Menurut Fikko (2020), dengan kekayaan alam yang membentang luas itulah, maka masyarakat diharuskan untuk menjaga dan melestarikan kekayaan alam yang tersedia dan berlimpah itu. Sehingga sebagian besar masyarakat Indonesia dapat menggantungkan kehidupannya diperairan. Mulai dari menjadi nelayan, kolam ikan, pengangkut barang, pedagang, objek wisata, dan juga digunakan orang-orang sebagai kendaraan umum untuk melewati perairan.

Tetapi seperti yang bisadilihat sekarang semua generasi muda gengsi untuk memilih jurusan di perguruan tinggi mengenai kealaman, padahal peluang kerjanya sangat besar dan tenaga kerja sangat dibutuhkan di negara kita tercinta ini. Akan tetapi, apabila memang tidakmemilikifashion di bidang kealaman, maka tidak mengapa memilih jurusan lain, yang terpenting adalah menyadari pentingnya kerja sama untuk membangun Indonesia ini, salah satunya dengan menjalani pendidikan. Sebab sekarang sudah memasuki era global dimana yang menjadi saingan untuk mendapatkan pekerjaan bukanlah terbatas hanya di lingkaran negara Indonesia saja tetapi juga dengan bangsa asing dari negara lain. Apabila yang mengurus negara ini adalah bangsa dari negara lain, bisa dibayangkan betapa suramnya kehidupan bangsa ini kedepannya. Dimana bangsa-bangsa negara lain tersebut dapat dengan mudah menjadi raja di negara ini serta memperbudak bangsa Indonesia. Kemungkinan buruk selanjutnya Indonesia akan mengalami krisis sebab kekayaan sudah beralih ke tangan bangsa asing.

Mengingat situasi negara yang terus dilanda krisis akhir-akhir ini, semua pihak yang terlibat di bidang pendidikan prihatin dengan situasinya dan mengkhawatirkan apa yang akan terjadi pada generasi berikutnya.

Apakah pendidikan di Indonesia ini setara dengan negara-negara lain di dunia? Untuk menjawab pertanyaan ini, penting untuk mempelajari reformasi apa yang perlu dilakukan di sektor pendidikan di Indonesia. Pertama, perkembangan teknologi informasi dan komunikasi menjadi salah satu penyebab perubahan paradigma baru pendidikan di abad ke-21.

Dalam konteks pemanfaatan teknologi informasi dan komunikasi dalam pendidikan, fakta membuktikan bahwa teknologi informasi dan komunikasi dapat mereduksi dan memadukan "ruang dan waktu" menjadi aspek yang menentukan kecepatan dan keberhasilan ilmu pengetahuan. Sejalan dengan hal tersebut, kemajuan teknologi informasi dan komunikasi telah menyebabkan penggantian sebagian besar tenaga kerja manusia dengan mesin, yang akan melakukan lebih banyak tugas setiap hari, manusia akan lebih banyak melakukan tugas intelektual dan kreatif tidak dapat dipungkiri bahwa sebagian besar pelajar dan anak Muslim saat ini dilahirkan sebagai digital natives, bukan digital 
immigrants.

Pada abad ke-21, kemajuan teknologi tersebut telah merambah ke segala aspek kehidupan, termasuk pendidikan. Pendidik dan siswa harus memiliki keterampilan mengajar abad ke-21. Untuk bertahan di era pengetahuan era informasi ini, pendidik dan siswa harus menghadapi banyak tantangan dan peluang. Pendidikan abad ke-21 bertujuan untuk mewujudkan cita-cita bangsa dengan membentuk masyarakat yang terdiri dari sumber daya manusia yang berkualitas, yaitu individu yang mandiri, yaitu negara Indonesia yang sejahtera dan bahagia yang menikmati kejayaan dan kesetaraan dengan negara lain. Di dalam dunia, bersedia dan mampu mewujudkan cita-cita negaranya. Abad 21 baru berjalan, namun telah terjadi beberapa kali perubahan di bidang pendidikan, perubahan tersebut sangat penting untuk tataran filosofi, arah dan tujuan. Untuk itu perlu diketahui perubahan bagaimana yang baik untuk terus diterapkan di Indonesia ini. Sebab seperti yang kita lihat generasi bangsa ini belum mampu untuk bersaing secara global di era global ini, dengan demikian perlu ditinjau lagi dari pendidikan di Indonesia ini, mulai dari sistem pendidikannya sampai sumber daya manusia seperti apa yang dibutuhkan di abad sekarang dan yang akan datang. Dengan demikian diharapkan kualitas pendidikan Indonesia akan meningkat dan melahirkan generasi bangsa yang lebih kompeten di bidangnya masing-masing. Sehingga bangsa Indonesia akan semakin maju dan terus dipandang baik di mata bangsa lain. Bangsa lainpun akan takut untuk menjajah negara tercinta ini.

\section{METODE}

Fokus artikel ini adalah pada reformasi pendidikan di abad 21. Pertanyaan yang akan dijawab dalam artikel ini adalah bagaimana seharusnya reformasi pendidikan Indonesia merespon tantangan abad 21? Secara reflektif, penelitian ini berharap dapat meninjau ide, metode pengobatan dan / atau situasi yang ada, terutama mengenai reformasi pendidikan abad ke-21 dan tantangannya. Dalam penelitian ini metode yang digunakan penulis adalah metode literatur (Zed, 2004), dan metode literatur terkait adalah metode yang digunakan penulis dengan mencari, mengumpulkan, menggali, atau memeriksa berbagai referensi atau dokumen yang berkaitan dengan topik yang diajukan (Sofiyah, Suhartono, \& Hidayah, 2020). Kemudian menggunakan teknik analisis isi dengan metode historis dan filosofis untuk analisis. Untuk penelitian ini digunakan satu artikel terkait untuk menunjang penelitian dengan didukung dari berbagai sumber penelitian lainnya.

Kata kunci: reformasi, pendidikan, dan tantangan abad 21.

\section{HASIL dan DISKUSI}

Menurut Mustinda (2020) Indonesia adalah negara berkembang di Asia (lebih tepatnya Asia Tenggara). Di negara dan wilayah berkembang, untuk menjadi negara maju dibutuhkan beberapa faktor, dan untuk membangun suatu negara menjadi negara maju menurut Anonim (2020) dibutuhkan beberapa faktor yaitu: sumber daya alam dan sumber daya manusia. Namun tanpa didukung kualitas 
sumber daya manusianya sendiri, sumber daya alam akan menjadi sia-sia, oleh karena itu sebagai negara berkembang Indonesia harus meningkatkan kualitas sumber daya manusia di Indonesia.

Salah satu cara untuk meningkatkan sumber daya manusia Indonesia menurut Anonim (2016) adalah dengan meningkatkan kualitas pendidikan di Indonesia sedini mungkin mulai dari kelompok hiburan/anak-anak, taman kanak-kanak, sekolah dasar, sekolah menengah pertama, sekolah menengah atas/ sekolah kejuruan hingga perguruan tinggi dan universitas. Namun, kualitas pelatihan keterampilan non akademik juga harus ditingkatkan.

Namun pendidikan di Indonesia masih menyedihkan, dari pendidikan anak usia dini hingga pendidikan tinggi masih banyak ruang untuk perbaikan. Salah satu kelemahan pendidikan Indonesia adalah bentuk kurikulum yang pertama. Kurikulum Indonesia memaksa siswa terlalu banyak membaca materi, kalaupun hanya berupa penjelasan, yang ada hanya imajinasi, dan praktiknya masih sangat sedikit. Oleh karena itu, sulit bagi seorang siswa untuk memahami apa yang dia pelajari. Kedua, menurut Susanti (2020) fasilitas yang masih belum merata di seluruh wilayah Indonesia. Menyediakan fasilitas yang memadai bagi lebih dari 17.000 orang Indonesia tidaklah mudah, terlebih di daerah terpencil, namun pendidikan Indonesia harus mempunyai fasilitas yang memadai untuk menunjang kualitas pendidikan sehingga membantu Indonesia untuk berkembang.

Alasan ketiga adalah kualitas guru di Indonesia yang rendah, banyak guru yang masih memiliki keterampilan mengajar yang buruk, karena masih banyak masyarakat Indonesia yang masih kurang menghargai guru atau profesinya, dan reputasi guru yang masih kurang baik bagi guru Indonesia. Namun kini, seiring dengan kebijakan dan kebijakan yang berulang kali diumumkan oleh pemerintah, pendidikan Indonesia mengalami kemajuan baru. Misal: Kebijakan pengembangan mutu dan peningkatan jumlah SMK di Indonesia memungkinkan siswa memiliki keterampilan yang lebih dan praktik yang sesuai di SMA. Dengan diterapkannya SMA, dengan diterapkannya mata kuliah 2013 siswa dapat menjelaskan sendiri apa yang telahdipelajari. Pengetahuan telah dipelajari sehingga siswa harus memahami sepenuhnya untuk tidak sepenuhnya menghafal materi.

Semakin banyak fasilitas yang dialokasikan ke daerah-daerah terpencil untuk meningkatkan kualitas sekolah, tentunya juga dapat meningkatkan kualitas sumber daya manusia dan kualitas guru. Salah satunya dengan mengadakan banyak seminar pelatihan untuk meningkatkan mutu pendidikan. Meningkatkan kemampuan guru dalam mengajar dan memahami situasi siswa, serta mengeluarkan kebijakan kesejahteraan guru, kebijakan tersebut membuat semakin banyak guru menjadi guru yang andal dan membuat guru lainnya merasa perlu terapung untuk meningkatkan daya saingnya. Perkembangan ini diharapkan dapat mempercepat pembangunan negara Indonesia dan menjadikan Indonesia sebagai negara maju di Asia. Namun tanpa kemauan dan kontribusi kita sebagai bagian dari SDM, semua ini sia-sia. Jadi mari kita bangun negara kita bersama.

Salah satu tujuan pendidikan nasional adalah kehidupan pendidikan negara. Ini adalah tanggung jawab besar bagi keluarga, sekolah dan pemerintah menerapkannya. Sejauh ini, belum ada model pendidikan yang tepat untuk siswa, yang dapat dibuktikan keluhan disebabkan oleh fakta 
seperti menurunnya kualitas pendidikan dari prasekolah hingga universitas.

Berbicara tentang sistem pendidikan, yang dipikirkan hanyalah hal-hal seperti kurikulum, metode pengajaran, peran guru, penilaian dan kondisi sekolah pribadi. Yang pertama adalah kurikulum nasional yang sepertinya bertarget di semua tingkatan, ini lebih banyak kuantitas daripada kualitas. Masa kanak-kanak adalah masa permainan, tetapi siswa sekolah dasar hampir tidak punya waktu Bermain, karena kurikulumnya terlalu berat ( 9 mata pelajaran), belum lagi pekerjaan rumah (PR) yang kebanyakan natural Ingatlah hal-hal yang tidak perlu dan terkadang tidak penting Kehidupan sehari-hari, terutama kehidupan menghadapi abad ke-21. Situasinya berbeda Di sekolah asing, kursus dasar hanya mencakup Matematika, ilmu bahasa dan pendidikan jasmani lainnya bersifat opsional.

Pada abad ke-21 akan tiba masalah atau kemajuan teknologi yang menjangkau jauh setiap bidang. Siapkah kita menghadapinya? Balasan pertanyaan ini perlu diketahui seperti apa sistem pendidikan manusia perlu memenuhi tantangan abad mendatang.

Pada konferensi tahunan UNESCO di Melbourne dari 29 hingga 30 Maret Pada tanggal 3 April 1998 yang dihadiri 60 negara, Carneiro (1998) menganggap pergantian abad adalah waktu yang tepat. Renungkan prestasi pendidikan. (Diptoadi, 1999)

Selama berabad-abad, pendidikan memainkan dua peran, yaitu pelestarian dan pembebasan, yang niscaya menimbulkan konflik dan kontradiksi. Namun, tak bisa dipungkiri bahwa menurut Diptoadi (1999) pendidikan adalah intinya masyarakat, karena pendidikan merupakan kekuatan potensial untuk pembebasan manusia dan menyingkirkan segala jenis perbudakan terhadap bangsa, serta menyingkirkan keterbelakangan. Selain itu, pendidikan dapat membantu masyarakat mengetahui apa yangbelumdiketahuisertaperluuntukdiketahui oleh masyarakat, serta membantu menempatkan keberadaan masyarakat di lingkungan yang tepat sehinggamembantu masyarakat bersiap untuk perubahan atau penerimaan keputusan tentang masa depan.

Pada abad 21 ini pasti negara-negara asing semakin gencar melakukan perbaikan terusmenerus bagi sistem pendidikannya serta terus melakukan pendidikan agar negara mereka yang maju akan terus semakin di depan.

Indonesia yang masing terkategorikan sebagai negara berkembang, haruslah lebih gencar lagi melakukan perbaikan sistem pendidikan. Apabila tidak adanya perbaikan maka negara ini akan semakin tertinggal.

Idealisme harus terus dikembangkan mengenai pendidikan. Menurut Anonim (2021) kemampuan softskill harus terus ditingkatkan, begitu pula dengan keterampilan yang lain harus diasah untuk menambah kemampuan, sehingga memiliki kemampuan banyak.

Teknologi menjadi salah satu aspek yang perlu ditingkatkan lagi fokusnya di negara ini. Sebab seperti yang bisadilihatbahwateknologi sekarang sudah sangat mengalami kemajuan, negara ini tidak boleh buta terhadap kemajuan zaman mengenai teknologi.

Indonesia merupakan negara kaya raya dengan kekayaan alam yang melimpah ruah salah 
satunya menghasilkan karet (Yolanda, 2020), sebenarnya dengan demikian sebaiknya bangsa Indonesia mampu mengolah bahan mentah tersebut sendiri, sehingga menjadi produk yang lebih dinilai atau dihargai, sehingga dapat menambah nilai jualnya.

Indonesia juga memiliki kekayaan alam bawah laut sangat banyak, dengan demikian maka bangsa Indonesia sebenarnya tidak akan merasa kelaparan di negara sendiri. Namun, pada kenyataannya krisis ekonomi terus menghantui negara ini.

Pendidikan yang merata bagi bangsa Indonesia dengan menanamkan pemahaman terhadap pentingnya kemajuan di Indonesia ini sangat penting dilakukan. Pendidik seharusnya mampu memberi contoh yang baik kepada anak muridnya, pendidik perlu terus meningkatkan pendidikannya setinggi-tingginya, sehingga dengan meningkatnya kualitas pendidik, maka akan semakin meningkat kualitas generasi bangsa yang dihasilkan melaluin proses pembelajaran.

\section{KESIMPULAN}

Perjalanan reformasi pendidikan masih sangat panjang. Masih banyak lagi yang perlu dilakukan. Indonesia harus terus menyesuaikan diri dengan kemajuan zaman agar tidak tertinggal dengan bangsa lain. Idealisme yang dimilikibangsa masih membara meski kini diliputi berbagai krisis yang melanda bangsa Indonesia. Tanpa idealisme, orang akan mati, mungkin tidak tumbuh kuat, tidak terintegritas dan martabat bangsa akan menjadi lemah, dan bangsaini hanyalah robot atau mesin lelucon. Perlu dihidupkan obor idealisme akan menerangi karya bangsa Indonesia, yang merupakan sumber inspirasi bagi generasi muda menuju masa depan cerah di abad ke-21.

Indonesia perlu menambah hal-hal yang berhubungan dengan kemajuan zaman ke dalam sistem pendidikan. Salah satu hal terpenting dalam pendidikan yaitu keterampilan teknologi. Dengan menambah pengajaran dan pemahaman teknologi kepada generasi penerus bangsa diharapkan akan terwujudnya negara yang bangsanya mampu bersaing secara global. Bangsa harus menjajahi teknologi dan mengambil manfaat darinya, jangan sampai bangsa yang terjajah oleh teknologi tersebut.

Di era globalisasi seperti sekarang, yang semuanya membaur dengan bangsa lain termasuk dalam hal pekerjaan, maka perlu ditingkatkan kemampuan generasi bangsa ini agar tidak tersingkir oleh bangsa lain ketika mencari pekerjaan di negara tercinta ini.

Generasi bangsa harus menjadi generasi yang sejajar dengan bangsa lain agar agar mampu mengubah status negara dari berkembang menjadi maju. Tentu untuk memajukan Indonesia dibutuhkan kontribusi dari segenap bangsa Indonesia terutama generasi muda yang akan menjadi penerus bangsa untuk terus mengenyam pendidikan.

Para pemimpin negara, guru, serta profesi-profesi lainnya yang sedang dilakukan oleh orang dewasa lama-kelamaan mereka akan berhenti dari pekerjaannya itu, yang kemudian harus digantikan posisinya oleh generasi penerus bangsa yaitu anak muda sekarang ini. Sebab itu, para pemuda memiliki tanggung jawab yang besar terhadap negara tercinta ini. Semuanya harus disiapkan dari 
sekarang, agar tercapainya masa depan maju bagi Indonesia tercinta.

\section{UCAPAN TERIMA KASIH}

Dengan menyebut nama Allah SWT yang Maha Pengasih lagi Maha Panyayang, kami panjatkan puja dan puji syukur atas kehadirat-Nya, yang telah melimpahkan rahmat, hidayah, dan inayah-Nya kepada kami, sehingga kami dapat menyelesaikan artikel dengan judul "Reformasi Pendidikan Menghadapi Tantangan Abad 21".

Artikel ini telah kami susun dengan maksimal dan mendapatkan bantuan dari berbagai pihak sehingga dapat memperlancar pembuatan artikel ini. Untuk itu kami menyampaikan banyak terima kasih kepada semua pihak yang telah berkontribusi dalam pembuatan artikel ini.

Terlepas dari semua itu, kami dengan tangan terbuka menerima segala saran dan kritik dari pembaca agar artikel ini semakin baik.

Akhir kata kami berharap semoga artikel dengan judul "Reformasi Pendidikan Menghadapi Tantangan Abad 21" mampu memberi manfaat.

\section{REFERENSI}

Anonim. (24 Desember 2016). Menyiapkan SDM Unggul yang Mampu Bersaing di Era Global. UGM. (Online), (https://alumni.ugm.ac.id/2016/12/24/menyiapkan-sdm-unggul-yangmampu-bersaing-di-era-global/), diakses 12 Maret 2021.

Anonim. (27 Mei 2020). Potensi dan Upaya Indonesia Menjadi Negara Maju. Kompas. (Online), (https://www.google.co.id/amp/s/amp.kompas.com/skola/read/2020/05/27/170000669/potensi -dan-upaya-indonesia-menjadi-negara-maju), diakses 10 Maret 2021.

Anonim. (09 Februari 2021). Mahasiswa Harus Seimbangkan Soft Skills Dan Hard Skills, Ini Manfaatnya. Binus . (Online), (https://onlinelearning.binus.ac.id/2021/02/09/mahasiswaharus-seimbangkan-soft-skills-dan-hard-skills-ini-manfaatnya/), diakses 10 Maret 2021.

Diptoadi, V. (1999). Reformasi Pendidikan di Idonesia Menghadapi Tantangan Abad 21. Jurnal Ilmu Pendidikan, 6 (3), 1-15. Malang: UNM. DOI: http://dx.doi.org/10.17977/jip.v6i3.2333.

Fikko, Muhammad. (15 Desember 2020). Pengelolaan Potensi Sumber Daya Laut Indonesia. Tekno dan Sains. (Online), (https://www.google.co.id/amp/s/m.kumparan.com/amp/muhammadfikko/pengelolaan-potensi-sumber-daya-laut-indonesia-1umeMOamuDr), diakses 12 Maret 2021.

Mustinda, L. (28 September 2020). Negara Berkembang. Detik Travel. (Online), (https://travel.detik.com/travel-news/d-5191583/negara-berkembang-di-dunia-ini-daftarlengkapnya), diakses 12 Maret 2021. 
Sofiyah, S., Suhartono, \& Hidayah, R. (2020). Jurnal Pendidikan Indonesia, Studi Literatur, (Online), (https://journal.uniku.ac.id/index.php/pedagogi), diakses 10 Maret 2021.

Sithu, Aung. (19 Juni 2015). Indonesia. UNY. (Online), (http://kuik.uny.ac.id/aung-si-thu-myanmarkekasih-negara-indonesia), diakses 11 Maret 2021.

Susanti, Dewi. (04 Februari 2020). Tantangan Pelaksanaan Pendidikan Dasar di Daerah Perdesaan dan Tertinggal. Indonesian. (Online), (https://blogs.worldbank.org/id/eastasiapacific/tantangan-pelaksanaan-pendidikan-dasar-didaerah-perdesaan-dan-tertinggal), diakses 10 Maret 2021.

Yolanda, Cindy. (30 Desember 2020). Indonesia Ternyata Jadi Salah Satu Negara Penghasil Karet Terbesar Dunia. Good News from Indonesia. (Online), (https://www.google.co.id/amp/s/www.goodnewsfromindonesia.id/2020/12/30/indonesiaternyata-jadi-salah-satu-negara-penghasil-karet-terbesar-dunia/amp), diakses 11 Maret 2021. 